\title{
Viscum Album (Ökse Otu) Ekstrelerinin Antimikrobiyal, Antioksidan ve Antidiyabetik Etkilerinin Belirlenmesi
}

\author{
Dorukhan KÖSEOĞLU1 ${ }^{1}$, Filiz Gökçenaz YİĞİT², Gülüşan TUNCAY ${ }^{3}$, Kadriye ÖZCAN ${ }^{*}$
}

\section{Öz}

Doğada bulunan birçok bitki, fenolik bileşik yönünden zengin olup doğal antioksidan ve antimikrobiyal özellikler taşımaktadır. Bu nedenle, bitkiler biyoteknolojik alanda önem kazanmaya ve kronik hastalıkların tedavisi için alternatif kaynak olarak tercih edilmeye başlanmıştır. Günümüzde önemli bir sağlık sorunu olan diyabet hastalığının tedavisinde anti-diyabetik özellik taşıyan bitkilerin kullanılabileceği düşünülmektedir. Bu özelliğinden dolayı bitkiler, son yıllarda araştırmacıların odak konusu haline gelmiştir. Bu bitkilerden birisi olan ve birçok hastalığın tedavisinde kullanılan ökse otunun (Viscum album), diyabet hastalığının tedavisi için de etkili olabileceği düşünülmüştür. Bu sebeple, bu çalışmada Artvin Arhavi bölgesinden toplanan armut ağacı üzerinde yetişen ökse otu bitkisinin üç farklı çözgen (kloroform, aseton, etanol) ile hazırlanmış ekstrelerinin fenolik ve flavonoid madde, antioksidan kapasite, antimikrobiyal aktivite ve enzim inhibisyon aktivite tayinleri yapılmıştır. Çalışmadan elde edilen sonuçlar göz önüne alındığında günümüzde yüksek bir biyolojik aktiviteye sahip olan ökse otu bitkisinin ilaç endüstrisinde kullanım potansiyelinin olduğu söylenebilir.

Anahtar Kelimeler: Viscum album, antimikrobiyal, antioksidan, enzim inhibisyon, diyabet.

\section{Determination of Antimicrobial, Antioxidant and Antidiabetic Effects of Viscum Album (Mistletoe) Extracts}

\begin{abstract}
Many plants in nature are rich in phenolic compounds and have natural antioxidant and antimicrobial properties. Therefore, plants have started to gain importance in the biotechnological field and are preferred as alternative sources for the treatment of chronic diseases. Today, it is thought that herbs with antidiabetic properties can be used in the treatment of diabetes, which is an important health problem. Because of this feature, plants have become the focus of researchers in recent years. It is thought that the mistletoe (Viscum album), which is one of these plants and used in the treatment of many diseases, can also be effective for the treatment of diabetes. For this reason, in this study, phenolic and flavonoid substance, antioxidant capacity, antimicrobial activity and enzyme inhibition activity of extracts prepared with three different solvents (chloroform, acetone, ethanol) of mistletoe grown on pear tree collected from Artvin Arhavi region were investigated. When the results obtained from the study are taken into consideration, it can be said that the mistletoe plant, which has a high biological activity today, has a potential of use in the pharmaceutical industry.
\end{abstract}

Keywords: Viscum album, antimicrobial, antioxidant, enzyme inhibition, diabetes.

\footnotetext{
${ }^{1}$ Giresun Üniversitesi, Mühendislik Fakültesi, Genetik ve Biyomühendislik Bölümü, Giresun, Türkiye, koseogludorukhan@gmail.com ${ }^{2}$ Giresun Üniversitesi, Mühendislik Fakültesi, Genetik ve Biyomühendislik Bölümü, Giresun, Türkiye, gkcenzyiit@gmail.com ${ }^{3}$ Giresun Üniversitesi, Mühendislik Fakültesi, Genetik ve Biyomühendislik Bölümü, Giresun, Türkiye, glsn.tuncay@hotmail.com ${ }^{4}$ Giresun Üniversitesi, Mühendislik Fakültesi, Genetik ve Biyomühendislik Bölümü, Giresun, Türkiye, kadriye.ozcan@giresun.edu.tr
} 


\section{Giriş}

Doğada bulunan birçok bitki, hastalıkların tedavisinde doğrudan veya dolaylı olarak kullanılmıştır ve kullanılmaya devam edilmektedir. Şifa amaçlı kullanılan bu bitkilerden bir tanesi de ökse otu (Viscum album)'dur. Ökse otu, Santalales takımı, Loranthaceae familyasına ve Viscum cinsine bağlı olup köknar, çam, ladin, armut, vişne, kiraz, kabak ağaçları gibi ağaçlar üzerinde yetişen dört mevsim boyunca yeşil olan yarı asalak bir bitkidir (Shinde ve ark., 2012). Günümüze kadar yapılmış olan bilimsel çalışmalar Viscum album bitkisinde, lektin (Wagner ve ark., 1986). viskotoksin, fenilpropan, lignan, flavonoid (Fukunaga ve ark., 1983), alkaloit ve poliholozit (Khıvaja ve ark., 1986) gibi çeşitli etken maddelerinin varlı̆̆ tespit edilmiştir.

Ökse otu, bakteri ve küf gibi mikroorganizmaların gelişimlerini engelleyerek antimikrobiyal özellikler sergilemekle birlikte, serbest radikaller tarafindan oluşturulabilecek oksidatif etkiyi ortadan kaldırarak hücre hasarını engelleyebilen antioksidan özelliğe de sahiptir. Bu özelliklerinden dolayı kanser ve kardiyovasküler hastalıklarının tedavisinde de kullanılmaktadır (Barney ve ark., 1998; Ergun ve ark., 1994).

Diyabet hastalığı hem insülin üretimi yetersizliği hem de insüline dirençten kaynaklanan yüksek kan glukoz düzeyi ile karakterize edilen kronik bir hastalıktır (Alberti ve Zimmet, 1998). Günümüzde epidemik bir hastalık haline gelmiş olan diyabet hastalığına yakalanan kişi sayısı, hızlı nüfus artışı, nüfusun yaşlanması, şehirleşme, obezite ve fiziksel inaktivite prevalansının artması nedeniyle giderek artmaktadır (Çubuk ve İnce, 2015). Hastalığın tedavisinde etkili yaklaşımlardan biri, karbohidratların monomerlerine hidrolizini azaltmaktır. Bu işlem, $\alpha$-amilaz ve $\alpha$-glukosidaz gibi karbohidrat hidrolizinden sorumlu anahtar enzimlerin aktivitesinin inhibe edilmesiyle başarılabilir. $\alpha$-amilaz, nişastada bol miktarda bulunan uzun zincirli karbohidratlar olan amiloz ve amilopektinin hidrolizinden sorumludur. $\alpha$-amilaz aktivitesinin bir sonucu olarak salınan serbest glukoz molekülleri bağırsaktan emilir ve kan dolaşımına geçer. Bu kan şekeri seviyelerinin yükselmesine neden olur. Bu enzimin inhibisyonu, serbest glukoz moleküllerinin oluşumunu azaltacağından, kan dolaşımına giren glukoz miktarı da azalır (Laube, 2002). Bazı bitki ekstreleri $\alpha$-amilazı inhibe eder ve glukozun emilimini geciktirerek diyabet hastalığının yönetimine etki etmektedir. $\mathrm{Bu}$ nedenle, bitkilerde bulunan anti-diyabetik aktivitenin tespiti için bitkilerdeki fitokimyasalların saptanması, izolasyonu ve saflaştırılması, araştırmacıların son yıllarda odaklandığı bir alan haline gelmişstir.

Tıbbi bitkilerin diyabet hastalığının tedavisi için araştırılmasının bir diğer büyük nedeni ise diyabet hastalığının tedavisinde kullanılan birçok yan etkiye sahip oral anti-diyabetik ajanlar yerine kullanılabilecek alternatif olarak düşünülmeleridir (WHO, 1980). Kullanılan sentetik veya yarısentetik anti-diyabetik ilaçların glukoz kontrolünü sağladığı, fakat hastalığın ilerlemesini durdurma konusunda etkilerinin sınırlı olduğu bilinmektedir. Ayrıca bu ilaçların hipoglisemi, 
iştahsızlık, bulantı, kusma, tıkanma ikteri, hematolojik sistem etkileri, deri lezyonları, uygunsuz ADH sekresyonu, troidde iyot alımının azalması gibi yan etkileri tespit edilmiştir (Duman ve Keser, 2018). $\mathrm{Bu}$ ilaçlara alternatif olarak bitkisel kaynaklı ajanların kullanılmasına olan yönelim çeşitli araştırmalar sonucunda oksidatif DNA hasarının ve birçok hastalığın tedavisinde $V$. album bitkisinin diyabet hastalığının kontrolünde de kullanılabileceğini düşündürmüştür. Çalışmamızda bu amaçla Artvin-Arhavi bölgesinden toplanan armut ağacı üzerinde yetişmiş olan ökse otu (V. album) bitkisinin toplam fenolik ve flavonoid madde içeriğgi, antioksidan kapasite, antimikrobiyal aktivite ve antidiyabetik etkinliği araştırılmıştır.

\section{Materyal ve Metot}

\subsection{Bitkilerin Toplanması}

Tez çalışmasında armut ağacı üzerinde yaşamsal faaliyet gösteren ökse otu kullanılmıştır. Bitki Doğu Karadeniz Bölgesi'nde yer alan Artvin ilinin Arhavi ilçesine bağlı olan Tepeyurt Köyü sınırları içerisinde 24 Ağustos 2019 tarihinde toplanmış, gölgede kurutulmuştur.

\subsection{Bitki Ekstrelerinin Eldesi}

Kurutulmuş bitki örnekleri, öğütücü yardımıyla öğütülerek analizler için uygun hale getirilmiştir. Ekstraksiyon işlemi için toz hale getirilen örnekler üç farklı çözgen kullanılarak ekstrakte edilmiştir. Çözgen olarak farklı polaritelere sahip olan etanol, aseton, kloroform kullanılmıştır. İşlem için öncelikle beş gram tartılan örnekler $100 \mathrm{ml}$ çözgen ile $125 \mathrm{rpm} 37^{\circ} \mathrm{C}$ 'yi aşmayacak şekilde gece boyunca çalkalayıcı inkübatörde bekletilmiştir. Daha sonra örnekler filtre kâğıdı kullanılarak bitki kısımlarından arındırılmıştır. Elde edilen süzüntüden çözücüyü uzaklaştırmak için vakum altında $37^{\circ} \mathrm{C}$ 'yi geçmeyecek sıcaklıkta evaporasyon gerçekleştirilmiştir. Elde edilen ekstreler ileri çalışmalar için $-20^{\circ} \mathrm{C}$ ’de muhafaza edilmiştir.

\subsection{Toplam Fenolik İçerik Tayini}

Ekstrelerin toplam fenolik içeriği Folin-Ciocaltaeu yönteminde (Slinkard ve Singleton, 1977) bazı değişiklikler yapılarak mikroplakalarda spektrofotometrik olarak belirlenmiştir (Acet ve Özcan, 2018). Reaksiyon için ilk olarak $31.25 \mu \mathrm{l}$ ekstre, $125 \mu \mathrm{l}$ folin reaktifi ve sodyum karbonat ile toplam hacim $250 \mu \mathrm{l}$ olacak şekilde gerçekleştirilmiş ve $750 \mathrm{~nm}$ 'de spektrofotometre ile okuma yapılarak sonuçlar gallik asit eşdeğerliği (mg GAE/g ekstre) olarak hesaplanmıştır. 


\subsection{Toplam Flavonoid Bileşen Tayini}

Ekstrelerin, toplam flavonoid madde miktarı, alüminyum nitrat kolorimetrik yönteminde bazı değişiklikler yapılarak mikroplakalarda spektrofotometrik olarak belirlenmiştir (Moreno vd., 2000). Ökse otu ekstraktları ve seyreltmeleri yapılan çözeltilerden $30 \mu \mathrm{l}$ alınarak sırasıyla $80 \mu \mathrm{l}$ metanol, 6 $\mu \mathrm{l} \% 10$ alüminyum klorür, $6 \mu \mathrm{l}$ potasyum asetat ve $125 \mu \mathrm{l}$ ultra saf su ilave edilmiş ve oda sıcaklığında karanlık ortamda reaksiyonun gerçekleşmesi için 30 dakika beklenilmiştir. Reaksiyon sonunda 415 nm dalga boyunda mikroplaka okuyucuda okuma işlemi gerçekleştirilmiştir. Sonuçlar kuersetin eşdeğeri olarak (mg QE/g ekstre) hesaplanmıştır.

\subsection{ABTS Radikali Giderme Tayini}

Ekstrelerin ABTS radikalini süpürme etkinliği yöntem üzerinde küçük değişiklikler yapılarak belirlenmiştir (Re ve ark., 1999). $80 \mu \mathrm{l}$ örnek ve örneğin üzerine $160 \mu 1 \mathrm{DPPH}$ çözeltisi pipetlenmiştir. Daha sonra altı dakika karanlık ortamda bekletilen karışımın etanol çözeltisine karşı 750 nm'de ölçümü yapılmıştır. Sonuçlar troloks eşdeğeri (mg TE/g ekstre) olarak hesaplanmıştır.

\subsection{DPPH Radikali Süpürme Aktivite Tayini}

Ekstrelerin DPPH radikali giderme özelliği, mikroplaka kullanılarak spektrofotometrik olarak belirlenmiştir (Kirby ve Schmidt, 1997). $125 \mu$ l örnek ve örneğin üzerine $125 \mu$ DPPH çözeltisi pipetlenerek mikroplakada 490 nm'de metanol çözeltisine karşı okuma yapılmıştır. Sonuçlar troloks eşdeğerliği (mg TE/g ekstre) olarak hesaplanmıştır.

\subsection{Disk Difüzyon Yöntemi}

Ekstrelerin konsantrasyon stokları kullanılarak disk difüzyon yöntemiyle antimikrobiyal aktivite tayin yapılmıştır (CLSI, 2017). İlk olarak mikroorganizmalar seyreltilmiştir (0.5 McFarland). Hazırlanan mikroorganizmalar eküvyon kullanılarak MHA petri üzerine yayma ekimle uygulanmıştır. Daha sonra ekimi yapılan petrilere boş diskler yerleştirilmiştir. Disklere $20 \mu \mathrm{l}$ ekstre uygulanmış ve besiyeriye difüze olması için $4^{\circ} \mathrm{C}$ 'de 2 saat bekletilmiştir. Petriler iki gün boyunca 37'de inkübasyona bırakılmış ve süre sonunda disklerin çevresinde oluşan inhibisyon zon çapı cetvel yardımıyla ölçülmüştür. 


\subsection{Minimum İnhibisyon Konsantrasyon Değerinin Belirlenmesi}

Disk difüzyon yönteminde inhibisyon zonu oluşturan mikroorganizmalar kullanılarak ekstrelerin MİK değerleri belirlenmiştir (CLSI, 2017). Test organizmaları (Proteus vulgaris ATCC 13315, Yersinia pseudotuberculosis ATCC 911, Pseudomonas aeruginosa ATCC 27583, Bacillus cereus RSKK 709, Escherichia coli ATCC 29998, Staphylococcus epidermidis ATCC 12228, Candida tropicalis NRLL YB-366, Enteroccus faecalis ATCC 29212) konsantrasyonları 0.5 McFarland bulanıklığına seyreltilmiştir. Öncelikle, MHB besiyeri mikroplaka kuyucuklarına aktarılmış ve daha sonra ilk kuyucuğa bitki ekstreleri eklenerek seri dilüsyon işlemi uygulanmıştır. Son olarak her kuyucuğa mikroorganizma eklenmiş ve $37^{\circ}$ 'de 48 saat boyunca inkübe edilerek mikroorganizma büyümesini engelleyen en düşük konsantrasyon değeri saptanmıştır.

\section{9. $\alpha$-amilaz Aktivite Tayini}

Ekstrelerin $\alpha$-amilaz inhibisyon aktivitesinin saptanmasında IKI yöntemi esas alınmıştır (Yang ve ark., 2012). Öncelikle, $25 \mu 1$ örnek, $50 \mu 1 \alpha$-amilaz çözeltisi ile karıştırılmıştır. Hazırlanan karışım 10 dakika boyunca $37^{\circ} \mathrm{C}$ 'de inkübasyona bırakılmıştır. İnkübasyon süresi dolduktan sonra nişasta çözeltisi (50 $\mu \mathrm{l} \% 0.05)$ ilave edilerek reaksiyonun başlaması sağlanmıştır. Karışım tekrar 37º de inkübasyona bırakılmış ve inkübasyon süresi bittikten sonra reaksiyonu durdurmak için karışıma 50 $\mu 1 \mathrm{HCl}(1 \mathrm{M})$ ve $200 \mu 1$ potasyum iyodür çözeltisi ilave edilmiştir. $630 \mathrm{~nm}$ ’de spektrofotometrik ölçüm yapılmış ve sonuçlar akarboz eşdeğerliği (mmol ACAE/g ekstre) olarak hesaplanmıştır.

\section{Bulgular ve Tartışma}

Ülkemiz sınırları içerisinde bir tür ve bu türe bağlı üç alt türü içeren $V$. album bitkisi armut, köknar, ayva, elma gibi farklı ağaçlar üzerinde yaşamsal faaliyetini idame ettiren yarı parazit bir bitkidir (Gölse, 1955; Hofstetter, 1985; Miller, 1982; Nagl ve ark., 1989). V. album yaşamını devam ettirdiği bitkilerin su ve organik maddelerini ksilem aracılığıyla kullanır. V. album'un göstereceği kimyasal özellikler yarı parazit olarak bulunduğu ağacın türüne göre değişiklik gösterebilmektedir (Calder ve ark., 1983). Ayrıca günümüzde birçok sağlık sorununun tedavisinde kullanılan $V$. album'un Orta Çağ' da yazılmış olan birçok şifalı bitkiler kitabında da dalak yetmezliği, kısırlık, nefes darlığı, doğum hastalıklarının tedavisinde kullanıldığı belirtilmiştir (Franz, 1985; Bock ve ark., 2004). Tez çalışmasında Artvin'in Arhavi ilçesine bağlı 252 m yüksekliğine sahip Tepeyurt köyünden toplanan armut ağacı üzerinde yetişmiş olan V. album bitkisinin farklı çözgenler kullanılarak elde edilen ekstrelerinin toplam fenolik ve flavanoid madde miktarları, amilaz enzim inhibisyonları, 
antioksidan özellikleri ve antimikrobiyal aktiviteleri belirlenmiştir. Farklı çözgenlerin ekstraksiyon işlemini etkileyeceği ve buna bağlı olarak çalışmanın sonucuna tesir edecekleri ve ayrıca kullanılan farklı çözgenlerin sonuçlara pozitif veya negatif olarak nasıl bir etkide bulunacağının saptanması amacıyla birden fazla çözgen kullanılmıştır. Yürütülen çalışmada analizi yapılan ekstreler polarite değerleri birbirinden ayrı olan üç çözücü kullanılarak elde edilmiştir.

Toplam fenolik madde içeriğinin belirlenmesinde Folin-Coicalteu yöntemi kullanılmıştır. Elde edilen sonuçlar Şekil 1'de gösterilmiştir. En yüksek toplam fenolik madde kloroform ekstresinde (40.27士0.23 mg GAE/g ekstre) gözlemlenmiştir. Diğer iki çözücüde de fenolik miktar gözlemlense de kloroforma kıyasla oldukça düşüktür. Yapılan bir çalışmada farklı ağaçlar (Sorbus aucuparia L., Populus nigra L., Malus domestica) üzerinde yetişmiş olan ökse otu bitkisinin metanol ekstrelerinin içerdikleri fenolik madde miktarları saptanmıştır. Sırasıyla saptanan değerler şu şekildedir; $9.66 \pm$ $0.28,10.43 \pm 0.20,6.71 \pm 0.32 \mathrm{mg}$ GAE/g ekstre. Yapılan bir başka çalışmada ise Yıldız ve arkadaşları (2019) Trabzon bölgesinde yetişen ökse otu metanol ekstresinin toplam fenolik içeriğini 6.114 mg GAE/g ekstre olarak saptamıştır. Çalışmamızda kullanılan ökse otu armut ağacı üzerinde yetişmiştir. Literatürde bulunan verilerle kıyaslandığında bitkinin yetişmiş olduğu ağacın ve bölgenin bitkinin fenolik içeriğine etkisi olduğu söylenebilir. Ayrıca çözücü olarak çalışmamızda kullanılan kloroformun diğer çalışmaya kıyasla daha iyi bir etkiye sahip olduğu görülmektedir (Pietrzak ve ark., 2017).

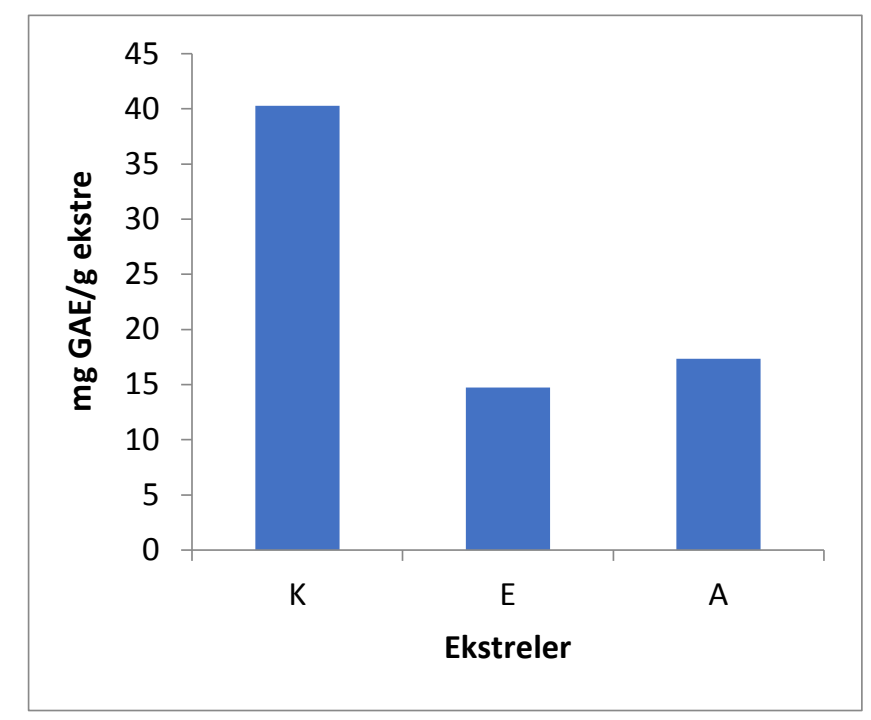

Şekil 1. Ekstrelerin mg GAE/g ekstre eşdeğerlik değerlikleri

Örneklerin toplam flavanoid içeriklerini tespit etmek için flavanoid grubuna bağlı olan bir flavanol olan kuersetin eşdeğerlik miktarının belirlenmesi temel alınmıştır. Kuersetinin önemli ölçüde antioksidan özelliğinin olduğu bilinmektedir. Ayrıca araştırmacılar için kuersetin, kansere karşı çözüm olarak umut kaynağıdır (Nam ve ark., 2016). Çalışmamızda ökse otu bitkisi etanol, 
kloroform ve aseton olmak üzere üç farklı çözücü ile muamele edilmiş ve toplam flavanoid içerikleri (mg QE/g ekstre) belirlenmiştir (Şekil 2). Yapılan analizler sonucunda sırasıyla toplam flavanoid içeriği 71.61 $\pm 5.93,106.94 \pm 12.28,81.74 \pm 8.69 \mathrm{mg}$ QE/g ekstre olarak belirlenmiştir. Yıldız ve arkadaşları (2019) Trabzon bölgesinden toplamış oldukları V. album ile yapmış oldukları çalışmada \%99 metanol ile muamele edilen ökse otu bitkisinin flavanoid içeriğini 2.73 mg QE/g ekstre olarak saptamıştır. İki ayrı çalışmada belirlenen değerler birbirinden oldukça farklıdır. Bu durum toplanan ökse otu bitkisinin farklı bölgelerden toplanmış olması ve buna bağlı olarak fitokimyasal içerikteki değişiklikten kaynaklandığını söylenebilir. Ayrıca kullanılan farklı çözücülerin de alınan sonuçlarda etkisi göz önünde bulundurulmalıdır.

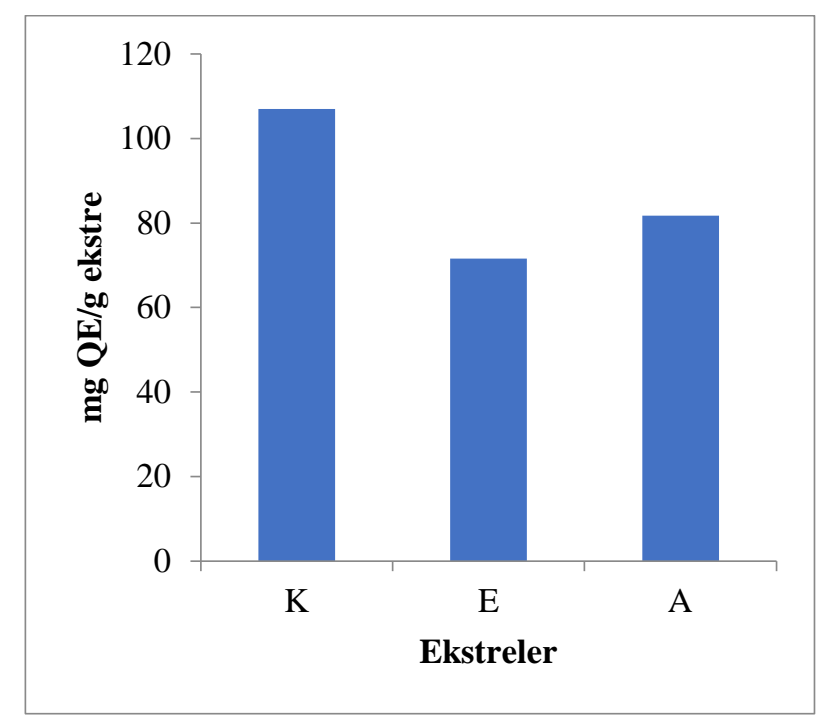

Şekil 2. Örneklerin mg QE/g ekstre eşdeğerlikleri

Ökse otu ekstrelerinin antioksidan özelliklerinin belirlenmesinde DPPH ve ABTS yöntemleri kullanılmıştır. Yapılan tayin sonucunda sonuçlar mg TE/g ekstre ve \% inhibisyon değerleri olarak Şekil 3 ve Şekil 4'de verilmiştir. DPPH analizi sonucunda troloks eşdeğerliği kloroform ve etanol örneklerinin değerleri birbirlerine oldukça yakın çıkmıştır ve değerler sırasıyla 41.14 mg TE/g ekstre ve $41.13 \mathrm{mg}$ TE/g ekstre şeklindedir. \% inhibisyon değerlerine bakıldığında ise kloroform ekstresinin \%75.96 gibi oldukça yüksek bir değere sahip olduğu söylenebilir. Uçar ve arkadaşları (2006) yapmış oldukları çalışmada farklı ağaçlar üzerinde yetişen ökse otlarının metanol ekstrelerinin DPPH radikal giderimi \% inhibisyon değerlerini saptamıştır. Alınan \% inhibisyon sonuçları 59.52-95.12 değerleri arasında değişkenlik göstermektedir. Yaptığımız çalışmada armut ağacı üzerinde yetişmiş $V$. album'un \% inhibisyon değerleri 47.12-30.39 aralığındadır. Uçar ve arkadaşları (2006)'nın yaptığı çalışmayla mukayese edildiği zaman armut ağacı üzerinde yetişen $V$. album bitkisi için etanol, kloroform ve aseton ekstrelerinin daha düşük troloks eşdeğerliğine sahip olduğu görülmektedir. 
Sonuçların birbirinden farklı çıkmasının nedeninin ökse otunun konukçusu olduğu bitkiye bağlı olarak fitokimyasal özelliklerinin de değişkenlik göstermesi olabilir.
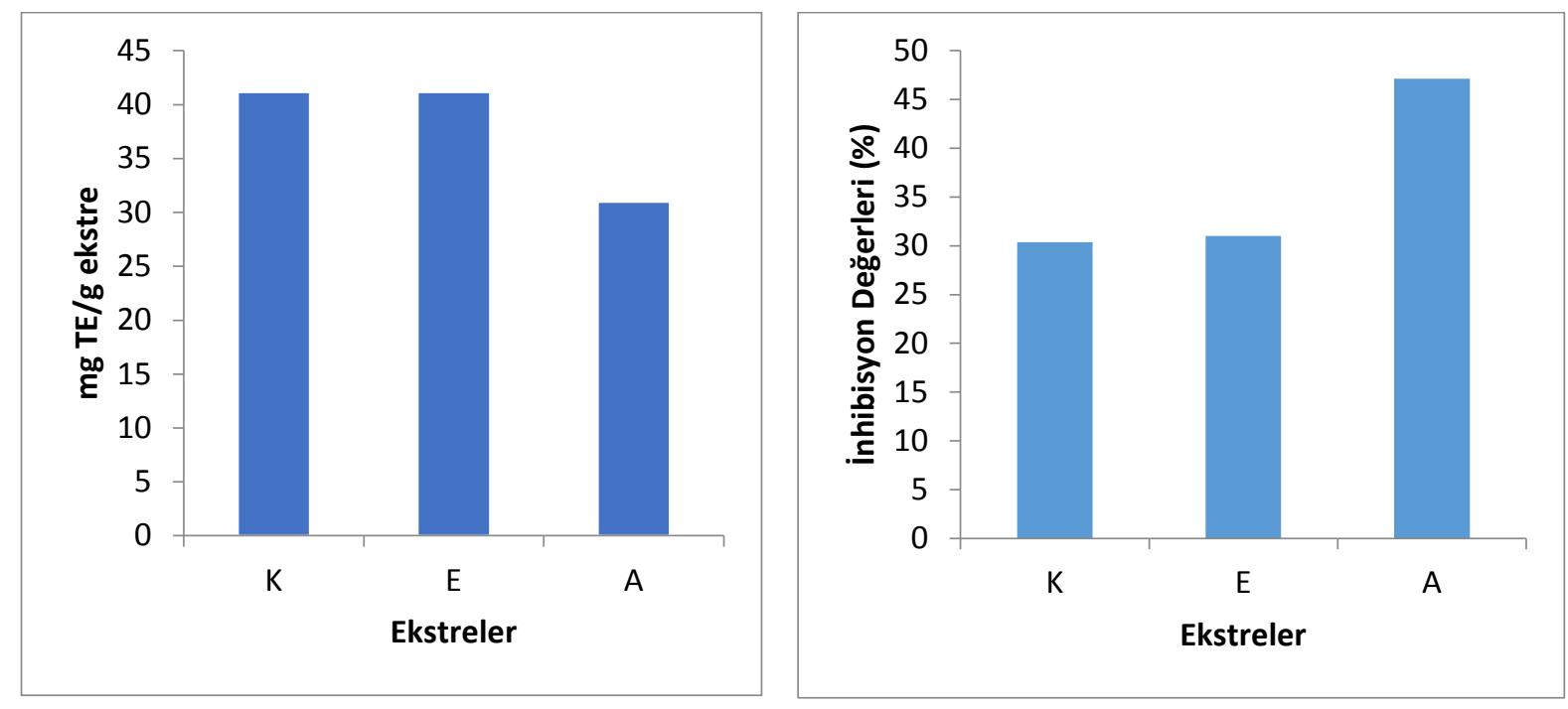

Şekil 3. Örneklerin ABTS metodu sonuçları kullanılarak hesaplanmış troloks eşdeğerliği ve \% inhibisyon değerleri

Yapılan bir diğer antioksidan kapasitesi tayin yöntemi olan ABTS analizinde ise mg TE/g ekstre olarak hesaplanan sonuçlarda kloroform, aseton ve etanol örneklerinin sonuçları birbirlerine yakın olmak ile birlikte en yüksek aktiviteye sahip ekstre 29.05 mg TE/g ekstre değeri ile aseton ekstresidir. Troloks eşdeğerliği yüksek olmasına karşın \% inhibisyon değerlerine bakıldığında en yüksek inhibisyon etkisine sahip olan örnek aseton örneğidir (\%67.06). Roman ve arkadaşları (2009) V. album bitkisinin ABTS tayininde saflaştırma basamağında milipor membran yöntemini temel alarak troloks eşdeğerlik tayini yapmıştır. Çözücü olarak distile su kullanılan örneğin troloks eşdeğerliği $241.37 \mu \mathrm{mol} / \mathrm{ml}$ hesaplanmıştır. Yaptığımız çalışmada elde edilen eşdeğerlik değerlerinin bu çalışmaya göre daha düşük olduğu söylenebilir. Bu durumun sebebi ekstraksiyon basamağında çalışmamızdan daha farklı yöntemleri kullanması ve buna bağlı olarak daha yüksek bir değer elde edildiği söylenebilir. 

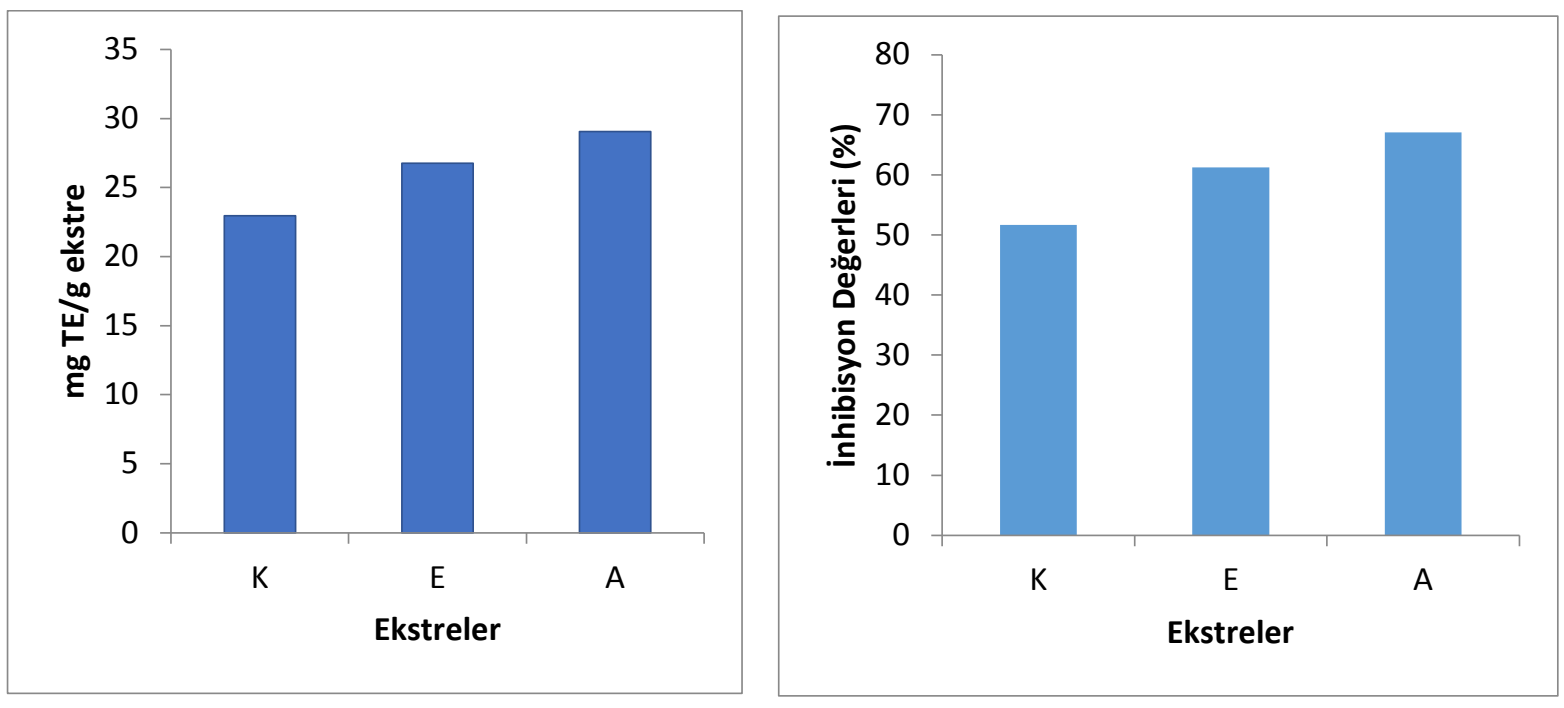

Şekil 4. Örneklerin DPPH metodu sonuçları kullanılarak hesaplanmış troloks eşdeğerliği ve \% inhibisyon değerleri

Ekstrelerin antimikrobiyal aktivitelerinin belirlenmesinde disk difüzyon ve mikrodilüsyon yöntemleri kullanılmıştır. Yapılan analizler sonucunda elde edilen disk difüzyon verileri Tablo 1'de ve MİK değerleri ise Tablo 2'de verilmiştir.

Tablo 1. Örneklerin disk difüzyon yöntemi sonuçları

\begin{tabular}{|c|c|c|c|c|}
\hline \multirow[b]{2}{*}{ Ekstreler ve Antibiyotik } & \multicolumn{4}{|c|}{ İnhibisyon Çapları (mm) } \\
\hline & Kloroform & Etanol & Aseton & Gentamisin \\
\hline \multicolumn{5}{|l|}{ Gram (+) organizmalar } \\
\hline B. cereus & 12 & 11 & 10 & 25 \\
\hline L. monocytogenes & - & - & - & 23 \\
\hline S. epidermidis & 10 & 11 & 11 & 28 \\
\hline E. faecium & - & - & - & 18 \\
\hline MRSA & - & - & - & 25 \\
\hline E. faecalis & 8 & - & - & 11 \\
\hline \multicolumn{5}{|l|}{ Gram (-) organizmalar } \\
\hline$V$. parahaemolyticus & - & - & - & 23 \\
\hline P. aeruginosa & - & - & 8 & 26 \\
\hline E. coli & - & - & 8 & 26 \\
\hline P. vulgaris & 12 & 12 & 11 & 29 \\
\hline S. typhimurium & - & - & - & 28 \\
\hline Y. pseudotuberculosis & 11 & 12 & 10 & 24 \\
\hline \multicolumn{5}{|l|}{ Maya } \\
\hline C. tropicalis & - & - & 10 & - \\
\hline
\end{tabular}

Disk difüzyon yönteminde kloroform ekstresi B. cereus ve $P$. vulgaris bakterilerine karş1 en yüksek inhibisyon etkisi göstermiştir. Göstermiş oldukları etkiye bağlı olarak zon çapları sırasıyla 12 ve 11 mm'dir. Ekstre maya türüne karşı herhangi bir inhibisyon özelliği gösterememiştir. Etanol ekstresinde ise $P$. vulgaris ve $Y$. pseudotuberculosis bakterilerine karşı inhibisyon özelliği en üst seviyededir. Oluşan inhibisyon çapları ise ikisi içinde $12 \mathrm{~mm}$ 'dir. Son olarak aseton ekstresinde ise elde edilen en yüksek zon çapı $P$. vulgaris ve $S$. epidermidis bakterilerine karşıdır. Gözlemlenen zon 
çapı ise $11 \mathrm{~mm}$ 'dir. Üç ekstreninde ortak olarak Gram (-) bakteri olan P. vulgaris'e karşı bir inhibisyon etkisine sahip oldukları görülmüştür. Ayrıca üç ayrı ekstre ele alındığında maya türüne karşı tek etkinin aseton ekstresinde olduğu saptanmıştır.

Ertürk ve arkadaşları (2003), yapmış oldukları çalışmada aynı yöreden toplanmış olan V. album bitkisinin n-hekzan ekstresinin antimikrobiyal aktivitesini araştırmışlardır. Araştırma sonucunda birçok mikroorganizmaya karşı benzer sonuçlar alınsa da bazı mikroorganizmalara karşı inhibisyon çapları çalışmamızdan çok daha yüksek çıkmıştır. Bunun sebebinin, çalışmalarda kullanılan farklı çözücülerden ve test uygulamalarında kullanılan ekstre miktarından kaynaklandığını düşünmekteyiz. Yapılan başka bir çalışmada ise Kumar ve arkadaşları (2004) mango ağacı üzerinde yetişen ökse otunun antimikrobiyal aktivitesini saptamak için etanol ile ekstrekte edilmiş örneğe disk difüzyon yöntemi uygulamıştır. Bu iki çalışmada, etanol ile ekstrakte edilmiş ökse otu örneklerinin ortak olarak P. aeruginosa bakterisine karşı herhangi bir inhibisyon etkisi gözlemlenmemiştir. Sonuçların birbiri ile paralellik göstermesine dayanılarak ökse otu bitkisinin $P$. aeruginosa bakterisine karşı inhibe edici özelliğinin olmadığı söylenebilir. Fakat çalışmamızda aseton ekstresinin P. aeruginosa bakterisine karş1 8 mm'lik inhibe edici bir etkiye sahip olduğu saptanmıştır. Bu durumda çözücüler değiştikçe örneğin antimikrobiyal özelliğinin de değiştiği yorumu yapılabilir (Kumar ve ark., 2014).

Disk difüzyon testinde inhibisyon zonu gözlenen sonuçlar değerlendirilerek mikrodilüsyon yöntemiyle MİK değerleri tespit edilmiştir (Tablo 2). MİK değeri, kullanılan antimikrobiyal ajanın mikrobiyal büyümeyi inhibe ettiği en düşük konsantrasyondur. Dolayısı ile düşük MíK değeri, o örneğin yüksek inhibisyon aktivitesi olduğunu gösterir. Etanol, aseton ve kloroform ekstrelerinin üçü de Gram negatif bir bakteri olan $V$. parahaemolyticus ve $P$. vulgaris'e karşı inhibisyon etkisi göstermiştir. C. tropicalis mayasına karşı ise sadece aseton ekstresinin $32 \mu \mathrm{g} / \mathrm{ml}$ konsantrasyon değerinde inhibisyon gösterdiği belirlenmiştir. P. vulgaris için kloroform ekstresinin $32 \mu \mathrm{g} / \mathrm{ml}$, etanol ekstresinin ise $64 \mu \mathrm{g} / \mathrm{ml}$ MIKK değeri saptanmıştır. Alınan sonuçlar değerlendirildiğinde örneklerin $P$. vulgaris'e karşı önemli bir inhibe edici etkisi olduğu yorumu yapılabilir. Ohikhena ve arkadaşları (2017) kauçuk ağacı üzerinde büyüyen ökse otunun aseton, metanol ve etanol ekstrelerinin antimikrobiyal aktivitelerini saptamak için mikrodilüsyon yöntemi uygulamışlardır. Alınan sonuçlar genel olarak 1.5-2.5 mg/ml aralığında değişkenlik göstermektedir. İki çalışmada da ortak olarak çalışılmış Gram negatif bir bakteri P. aeruginosa'da sonuçlar değişkenlik göstermektedir. Yaptı̆̆ımız çalışmada armut ağacı üzerinde yetişmiş olan ökse otu bitkisinin aseton ekstresinde alınan minimum inhibisyon konsantrasyon değeri $32 \mu \mathrm{g} / \mathrm{ml}$ iken Ohikhena ve arkadaşları (2017) yapmış oldukları çalışmada kauçuk ağacı üzerinde yetişmiş olan ökse otu bitkisinin aseton ekstresinde belirlenen minimum inhibisyon konsantrasyon değeri $2500 \mu \mathrm{g} / \mathrm{ml}$ olarak belirlenmiştir. Dolayısı ile bitkimizin etkinliğinin daha yüksek olduğu görülmektedir. Bu durum göz önüne alınarak bitkinin yetişmiş olduğu ağaç türünün bitkinin fitokimyasal özelliklerinde ciddi bir etkisinin olduğu görüşüne 
varılabilir. Yapılan bir başka çalışmada ise Kumar ve arkadaşları (2004) mango ağacı üzerinde yetişen ökse otunun antimikrobiyal aktivitesini mikrodilüsyon yöntemini kullanarak belirlemiştir. Çözücü olarak etanol kullanılmış ve $P$. aeruginosa ile E. coli üzerine $500 \mu \mathrm{g} / \mathrm{ml}$ MİK değeri saptamışlardır. Çalışmamızda ise etanol ekstresinin bu organizmalar üzerinde herhangi bir aktiviteye sahip olmadığ1 görülmektedir. Fakat çalışmamızda E. coli bakterisine karşı aseton ekstresinde 64 $\mu \mathrm{g} / \mathrm{ml}$ MIKK değeri saptanmıştır. Veriler mukayese edildiği zaman daha önce belirtildiği gibi ökse otunun farklı ağaçlar üzerinde fitokimyasal özelliğinin değiştiği yorumu bu bulgular ile desteklenmektedir. Ayrıca farklı çözücülerin kullanılması örneğin değişmesine ve farklı sonuçların alınmasına neden olduğu da açıkça görülmektedir.

Tablo 2. Örneklerin minimum inhibisyon konsantrasyon değerleri

\begin{tabular}{lccc}
\hline & İnhibisyon Konsantrasyon Değerleri $(\boldsymbol{\mu g} / \mathbf{m l})$ & \\
\hline \multicolumn{1}{c}{ Mikroorganizmalar } & Kloroform & Etanol & Aseton \\
B. cereus & 128 & 128 & 128 \\
\hline L. monocytogenes & - & - & - \\
\hline S. epidermidis & 64 & 128 & 256 \\
\hline E. faecium & - & - & - \\
MRSA & - & - & - \\
E. faecalis & 64 & - & - \\
\hline V. parahaemolyticus & 64 & 128 & 128 \\
\hline P.aeruginosa & - & - & 32 \\
\hline E.coli & - & - & 64 \\
\hline P. vulgaris & 32 & 64 & 64 \\
\hline S. typhimurium & - & - & - \\
\hline Y. pseudotuberculosis & - & - & - \\
\hline C. tropicalis & - & - & 32 \\
\hline
\end{tabular}

Son zamanlarda bitkilerin aktif bileşenleri tedavi amaçlı olarak kullanılmaktadır. Yapay olarak geliştirilmiş olan kimyasal ilaçların çeşitli zararlı etkileri mevcuttur. Buna bağlı olarak doğal ürünlere yönelim artmıştır (Dabbas ve ark., 2006). Günümüzün en büyük sağlık problemlerinden birisi ise diyabettir. Diyabetin tedavisinde ise hipergliseminin yavaşlatılması önemli bir yaklaşımdır. Hipergliseminin yavaşlatılabilmesi için karbohidrat sindirim enzimi olan amilaz ve glukozidazın inhibe edilmesi ve buna bağlı olarak glukoz absorsbiyonun düşük değerlere çekilmesiyle sağlanır (Rahabasa-Lhoret ve ark., 2009). Çalışmamızda son olarak örneklerin $\alpha$-amilaz enziminin inhibisyon ve mMol akarboz eşdeğerlikleri belirlenmiştir. Etanol, kloroform, aseton ekstrelerinin $\alpha$-amilaz enziminin inhibisyon değerleri sırasıyla \%69.75, 75.96 ve 70.33 olarak saptanmıştır. Bu değerler göz önüne alındığı zaman kloroform ekstresinin $\alpha$-amilaz enziminin inhibisyon değerinin en yüksek 
olduğu görünmektedir. Orhan ve arkadaşları (2004) yapmış oldukları çalışmada V. album bitkisinin su ekstresinin \% $\alpha$-amilaz inhibisyon değerini $14.0 \pm 4.2$ olarak saptanmıştır. Yapılan bir başka çalışmada ise çalışmamızda bulunan değerler literatüre nazaran daha yüksektir. Bu verilere dayanarak çalışmamızda kullanılan $V$. album bitkisinin toplanan yöre ve kullanılan çözücülere bağlı olarak özellikle kloroform ekstresinin ciddi bir inhibisyon etkisine sahip olduğu söylenebilir. Yapılan başka bir çalışmada ise Stefanucci ve arkadaşları (2020) tarafından V. album bitkisinin yaprak bölümü kullanılmıştır. Ekstraksiyon yöntemimde homojenizatör destekli ektraksiyon yöntemi seçilmekle birlikte solvent olarak metanol tercih edilmiştir. Alınan sonuçlarda ekstrenin mmol akarboz/g ekstre değeri $0.98 \pm 0.01$ olarak saptanmıştır. Çalışmamızda ise en yüksek $275 \mathrm{mMol}$ akarboz/g ekstre değeri kloroform ekstresidir. İki çalışma değerleri karşılaştırıldığında çalışmamızda bulunan akarboz eşdeğerlik değeri literatüre kıyasla oldukça yüksek seviyelerdedir. Bunun sebebi ekstraksiyon yönteminin farklılığı, çözücünün farklılığı veya bitkinin gelişim göstermiş olduğu ağaç türünün farklılığından kaynaklanmaktadır. Orhan ve arkadaşları (2014) Ankara ilinden toplanmış olan V. album ssp. austriacum bitkisinin maserasyon infüzyon ekstraksiyon yöntemini kullanarak etanol ve su solventi ile ekstrakte edilmiştir. $1000 \mu \mathrm{g} / \mathrm{ml}$ konsantrasyon değerinde $\alpha$-amilaz enziminin inhibisyon değerleri sırasıyla $16.7 \pm 0.7$ ve $7.03 \pm 0.06$ olarak belirlenmiştir. Çalışmamızda ise aynı konsantrasyon değerlerindeki etanol, kloroform, aseton ekstrelerinin $\alpha$-amilaz enziminin inhibisyon değerleri sırasıyla \%69.75, 75.96 ve 70.33 olarak belirlenmiştir. İki çalışma mukayese edildiğinde çalışmamızda kullanılan bitkinin daha yüksek oranda enzim inhibisyon yeteneğine sahip olduğu söylenebilir. Değerlerin farklılık sebebi ise ökse otu bitkisinin yetişmiş olduğu ağaca bağlı olarak fitokimyasal özelliklerinin değişkenlik göstermesi söylenebilir. Ayrıca kullanılan ekstraksiyon yöntem tercihinin farklı oluşunun buna sebebiyet verdiği söylenebilir (Orhan ve ark., 2014). Oboh ve arkadaşları (2018) yapmış oldukları çalışmada Afrika bölgesinde yetişen ve ekmek ağacı üzerinde yaşamsal faaliyet gösteren ökse otu bitkisini \%80’lik aseton ile ekstrakte etmiş̧lerdir. $4 \mu \mathrm{g} / \mathrm{ml}$ konsantrasyon değerinde ekstrenin $\alpha$-amilaz enziminin inhibisyon değeri \%81 olarak belirlenmiştir. Aynı solvent ile kendi çalışmamızda almış olduğumuz değer 1000 pg/ml konsantrasyondaki ekstrakt için \%70.33 olarak belirlenmiştir. İki değer yorumlandığında bitkinin toplanmış olduğu bölgenin bitkinin özelliklerine olan etkisinin oldukça yüksek olduğu yorumu yapılabilir. Literatür taraması sonucunda bulmuş olduğumuz veriler ve kendi çalışmamız neticesinde ulaşmış olduğumuz sonuçlar göz önüne alındığı zaman ökse otu bitkisinin günümüzün en önemli hastalıklarından biri olan diyabete karşı bir doğal çözüm yolu olabileceğini ortaya koymaktadır. 

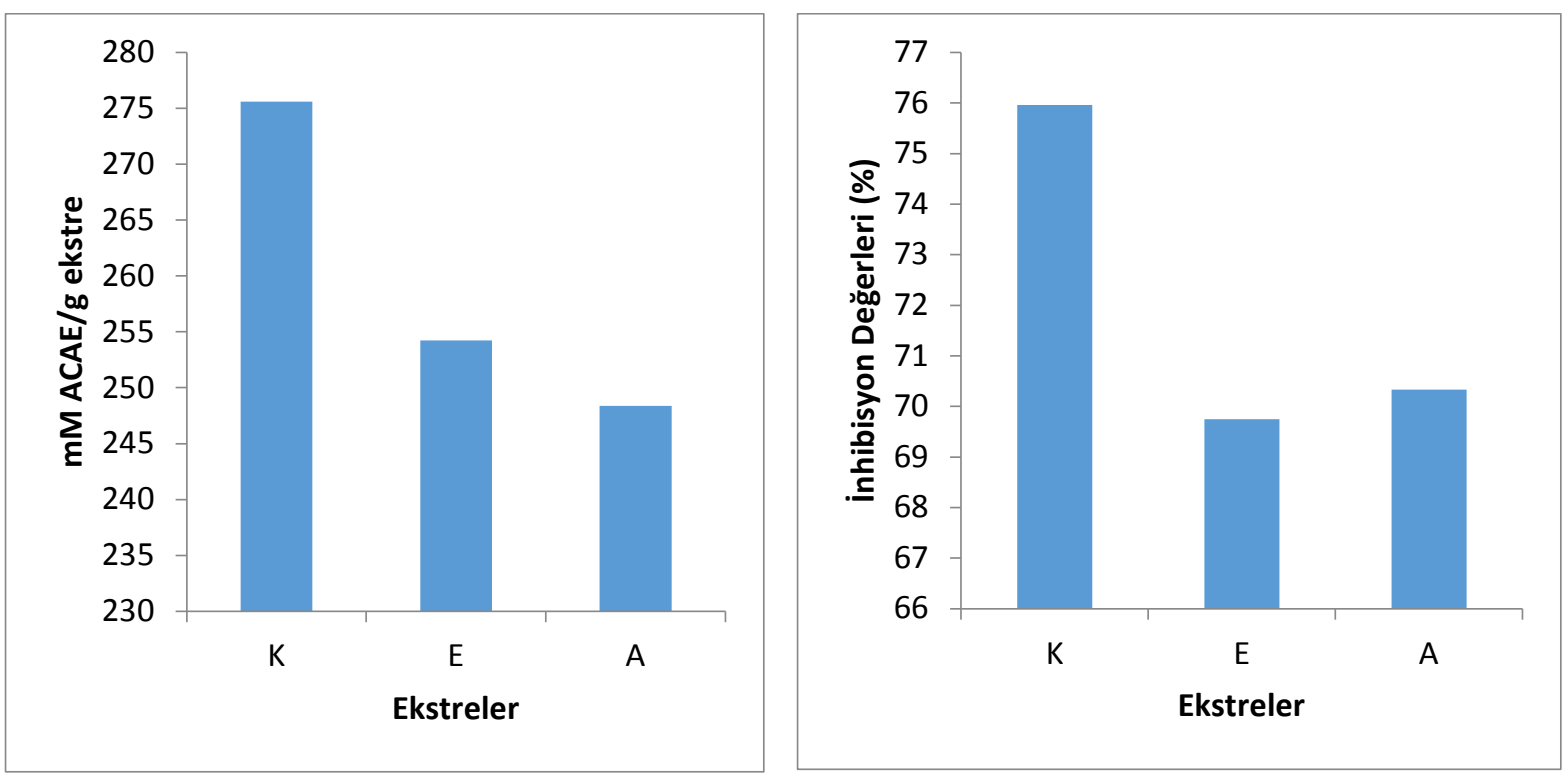

Şekil 5. Örneklerin mM akarboz eşdeğerliği ve \% inhibisyon değerleri

\section{Sonuçlar ve Öneriler}

Sonuç olarak, bu çalışmada Artvinde yetişen armut ağaçlarından toplanan ökse otunun antioksidan, antimikrobiyal ve antidiyabetik gibi bazı biyolojik aktiviteleri araştırılmıştır. Buna göre, bitkinin toplam fenolik ve flavonoid bileşik miktarının yüksek olduğu belirlenmiştir. İlaveten bitkinin antioksidan ve antimikrobiyal etkinliklerinin de kayda değer derecede güçlü olduğu tespit edilmiştir. Bununla birlikte; bu çalışma ile bitkinin, diyabetin kontrolünde önemli anahtar enzimlerden birisi olan $\alpha$-amilaz inhibisyon aktivitesi ilk defa belirlenmiştir. Bu sonuçlar, V. album bitkisinin ilaç endüstrisinde ve diyabet hastalığının yönetiminde kullanım potansiyelinin olduğunu düşündürmektedir.

\section{Kaynaklar}

Acet, T., ve Özcan, K. (2018). Aslanpençesi (Alchemilla Ellenbergiana) ekstrelerinin antioksidan ve antimikrobiyal özelliklerinin belirlenmesi. Gümüşhane Üniversitesi Fen Bilimleri Enstitüsü Dergisi, 8 (1), 113-121.

Alberti, K.G., and Zimmet, P.F. (1998). Definition, Diagnosis And Classification Of Diabetes Mellitus And İts Complications. Part 1: Diagnosis And Classification Of Diabetes Mellitus. Provisional Report Of A WHO Consultation. Diabetic Medicine, 15(7), 539-553.

Barney, C.W., Hawksworth F.G. and Geils B.W. (1998). Hosts of Viscum album. European Journal of Forest Pathology, 28, 187-208.

Bock, P.R., Friedel, W.E., Hanisch, J., Karasmann, M., and Schneider, B. (2004). Efficacy and safety of longterm complementary treatment with standardized european mistletoe extract (Viscum album L.) in addition to the conventional adjuvant oncologic therapy in patients with primary nonmetastasized mammary carcinoma/results of a multicenter, comparative, epidemiological cohort study in Germany and Switzerland. Arzneimittel Forschung. 54, 456-466. 
Calder, M., and Bernhardt, P. (1983). The biology of mistletoes. Fifth Avenue New York, US Acedemic Press Inc. 3, 23-25.

Clinical and Laboratory Standards Institute (CLSI), 2017. Performance Standards for Antimicrobial Susceptibility Testing; 27th Informational Supplement. CLSI/ NCCLS, 27th ed.; Clinical and Laboratory Standards Institute: Wayne, PA, USA.

Çubuk, G., and İnce, S. (2015). Oral Antidiabetic Drugs, Kocatepe Veterinary Journal, 8 (1), 95-102.

Dabbas, M., Kitahara, K., Suganuma, T., Hashimoto, F., and Tadera, K. (2006). Antioxidant and $\alpha$-amylase inhibitory compounds from Aerial parts of Varthemia iphionoides Boiss, Bioscience Biotechnology and Biochemistry, 70, 2178-2184.

Duman, E., ve Keser A. (2018). Saponinler ve Diabetes Mellitus Üzerine Potansiyel Etkileri. Ankara Sağllk Bilimleri Dergisi, 7(1), 50-60.

Ergun, F., Deliorman, D., ve Şener, B. (1994). Viscum album L. (Ökseotu) (Loranthaceae) Bitkisinin Morfolojik Özellikleri ve Türkiye'deki Yayılışı Hakkında Bazı Araştırmalar. Ot Sistematik Botanik Dergisi, 1(2),47-62.

Ertürk, Ö. (2003). Antimicrobial Activity of Viscum album L. Subsp. Abietis (wiesb). Turkish Journal Of Biology, 27 (4), 255-25.

Franz, H. (1985). Inhaltsstoffe der Mistel (Viscum album L.) als Potentielle Arzneimittel, Pharmazie. 40(2), 97-103.

Fukunaga, T., Kajikawa, I., Nishiya, K., Watanabe, Y., Silzsk1, N., Takeya, K., and Itokowa, H. (1983). Studies on the constitt1enis of the Europan mistletoe. Viscum Album L. iI, Chem. Pharm. Bull., 36 (3),11851189.

Gölse, J. (1955). Precis de Matière Medicale, Paris Fransa: G. Doin: Cie, Pari

Hofstetter, M. (1985). HPLC-Charakterisierung von Lektinen der Mistel (Viscum album L.) und Verbreitung der Pflanze in der Schweiz, Doktora Tezi, Eidgenössischen Technischen Hochschule Zürich, Zürich

Khivaja, T.A., Dias, C.B., and Pentecost, S. (1986). Recent studies on the anticacer activities of mistletoe (Viscum Album L) and its alkaloids. Oncology, 13(1), $42-50$.

Kirby, A.J., and Schmidt, R.J. (1997). The antioxidant activity of Chinese herbs for eczema and of placebo herbs. Journal of Ethnopharmacol. 56 (2), 103-108.

Kumar, K., Saraswathy, A., Amerjoth, S., and Ravishankar, B. (2014). Journal of tranditional and complemantary medicine, 4(4), 258-262

Laube, H. (2002). Acarbose An Update Of İts Therapeutic Use İn Diabetes Treatment. Clinical Drug Investigation, 22 (3), 141-156.

Miller, A.G. (1982). Viscum album L. Flora of Turkey and the East Aegean Islands. Edinburgh University Press, 547-548

Moreno, M.I.N., Isla, M.I., Sampietro, A.R., and Vattuone, M.A. (2000). Comparison of the free radicalscavenging activity of propolis from several regions of Argentina. Journal Ethnopharmacology, 71, 12, 109-114.

NagI, W., and Stein, B. (1989). DNA Characterization in Host- Spesific Viscum album Subspecies (Viscaceae), Plant Syst. Evol, 166 (3-4), 243-248.

Nam, J.S., Sharma, AR., Nguyen, L.T., Chakraborty, C., Sharma, G., and Lee, S.S. (2016). Application of bioactive quercetin in oncotherapy from nutrition to nanomedicine. MDPI Molecules 21 (1) 108.

Oboh, G., Babatola, LJ., and Ademiluyi, AO. (2018). In vitro inhibitory effects of mistletoes (Loranthus begwensis $L$.) phenolic-rich extracts on a-amylase, a-glucosidase, and angiotensin converting enzyme activities. Journal Food Biochem,42 (4) 12504-12508

Ohikhena, F.U., Wintola, O.A., and Afolayan, A.J. (2017). Evaluation of the Antibacterial and Antifungal Properties of Phragmanthera capitata (Sprengel) Balle (Loranthaceae), a Mistletoe Growing on Rubber Tree, Using the Dilution Techniques. The Scientific World Journal, 1-8

Orhan, N., Hoçbaç, S., Orhan, D., Asya, M., ve Ergun, F. (2014). Haziran Türkiye'nin bazı antidiyabetik bitkilerinin enzim inhibitör ve radikal süpürücü etkileri Journal Basic Med. Sci. 17 (6), 426-432.

Pietrzak, W., Nowak, R., Gawlik-Dziki, U., Lemieszek, M., and Rzeski, W. (2017). LC-ESI-MS/MS Identification of Biologically Active Phenolic Compounds in Mistletoe Berry Extracts from Different Host Trees. MDPI Molecules 22 (4), 624 doi:10.3390 / molecules22040624

Rahabasa-Lhoret, R., and Chiasson, J. L. (2009). $\alpha$-Glucosidase inhibitors. International Textbook of Diabetes Mellitus, 1,(3) 901-914.

Re, R., Pellegrini, N., Proteggente, A., Pannala, A., Yang, M., and Rice-Evans, C. (1999). Antioxidant activity applying and improved ABTS radical cation decolarization assay. Free Radic Biol Med, 26 (9-10), 12311237. 
Roman, G.P., Neagu, E., Radu, G.L. (2009). Antiradical Activities of salvia Officinalis and Viscum album L. Extracts Concentrated by ultrafiltration process. Acta Sci. Pol., Technol. Aliment. 8(3), 47-58.

Shinde, A., Ganu, J., and Naik, P. (2012). Effect of free radicals \& Antioxidants on oxidative stress. $J$ Dent Allied Sci. ,1(2), 63- 66.

Slinkard, K., and Singleton, V.L. (1977). Total phenol analysis: Automation and comparison with manual methods. American Journal of Enology and Viticulture, 28, (1) 49- 55.

Stefanucci, A., Zengin, G., and Martinez, E.J. (2020). Viscum album L. homogenizer-assisted and ultrasoundassisted extracts as potential sources of bioactive compounds. Journal of Food Biochem. 44 (9), https://doi.org/10.1111/jfbc.13377

Uçar, Ö., Karagöz, A., ve Arda, N. (2006). Viscum album ssp. antioksidan aktivitesi. Fitoterapia, 77 (7-8), 556-560.

Wagner, H., Feil, B., Seligmann, O., Petricic, I., and Kalogjera, Z. (1986). Phenylpropanes and lignans of Viscum Album L cardioactive drugs V., Planta Med., (2), 702-704.

WHO, (1980). Expert Committee On Diabetes Mellitus. Technical Report Series, World Health Organization, Geneva.

Yang, X.W., Huang, M.Z., Jin, Y.S., Sun, L.N., Song, Y., and Chen, H.S. (2012). Phenolics from Bidens bipinnata and their amylase inhibitory properties. Fitoterapia 83 (7) , 1169- 1175.

Yıldız, S., Gürgen, A., Kı1ıç, C., Tabbouche, S., Kılıç, A., ve Can, Z. (2019). Antioxidant, Antimicrobial, and Anti-Quorum Sensing Activities of Usnea filipendula and Viscum album. Anadolu Çev. ve Hay. Dergisi, 4(4), (613-620). 